\title{
Health system considerations related to voluntary and forced displacement in the Eastern Mediterranean Region: a critical analysis of the available literature
}

Eman Sharara, ${ }^{1}$ Chaza Akik, ${ }^{2}$ Michela Martini ${ }^{3}$ and Jocelyn DeJong ${ }^{1}$

${ }^{1}$ Faculty of Health Sciences, ${ }^{2}$ Center for Research on Population and Health (CRPH), American University of Beirut, Beirut, Lebanon (Correspondence to: Jocelyn DeJong: jd16@aub.edu.lb; dejongjocelyn@yahoo.com). ${ }^{3}$ International Organization for Migration Regional Office for East and Horn of Africa, Nairobi, Kenya.

\begin{abstract}
Background: The WHO Region for the Eastern Mediterranean has had a history of complex migration patterns, with high levels of migration to, from and within the Region, overlaid by massive recent forced displacement. Relatively little is known about the health system response to this large-scale mobility.

Aims: To review the literature on the Region critically, identify gaps and suggest areas needing research and policy attention.

Method: A search of the published literature using MEDLINE and POPLINE was conducted on health and migration focusing on the WHO health system building blocks with no date or language limitations.

Results: Out of 4679 retrieved articles published between 1964 and January 2019, 140 met our inclusion criteria; 45 additional articles were included in a December 2020 update. Most publications focused on refugees and on the delivery of services.

Conclusions: Few studies explored the responsiveness of health system to refugees and migrants compared with those for host communities, or assessed the quality of services or refugees'/migrants' perceptions of available health services. Few suggested new approaches to financing health care access for these populations or new governance arrangements.

Keywords: refugees, migrants, health systems, Eastern Mediterranean Region

Citation: Sharara E; Akik C; Martini M; DeJong J. Health system considerations related to voluntary and forced displacement in the Eastern Mediterranean Region: a critical analysis of the available literature. East Mediterr Health J. 2021;27(12):1214-1228. https://doi.org/10.26719/emhj.21.071

Received: 11/03/21; accepted: 22/08/21

Copyright $@$ World Health Organization (WHO) 2021. Open Access. Some rights reserved. This work is available under the CC BY-NC-SA 3.o IGO license (https://creativecommons.org/licenses/by-nc-sa/3.o/igo).
\end{abstract}

\section{Introduction}

\section{Background}

The World Health Organization (WHO) Region for the Eastern Mediterranean (EMR) has experienced continuous movements of voluntary and forced migration, within the Region and within countries, with forced displacement in particular increasing in recent years. Massive humanitarian crises in many countries of the Region - such as in Afghanistan, Iraq, Libya, Somalia, Sudan, Syrian Arab Republic and Yemen - are overlaid on longstanding and complex migration pathways within, from and into the Region. Intraregional and cross-regional economic disparities and job opportunities, in both the formal and informal sector, lead to large labour migration flows (i.e. both emigration and immigration), involving highly skilled and low skilled migrants. There is a marked vulnerability among the latter, particularly in the domestic and construction sectors and in manual work generally (1). Much of the intra-regional movement has been destined for the high-income countries of the Gulf Cooperation Council, which host disproportionately high numbers of international migrants.
With conflicts increasing in recent years, however, both low- and middle-income countries of the Region in particular are simultaneously hosting migrants and refugees, while sending migrants within the Region and abroad. As of the end of 2018 , about $67 \%$ of the world's refugees originated from just 5 countries, 3 of which are in the EMR: Syrian Arab Republic (6.7 million), Afghanistan (2.7 million) and Somalia (0.9 million) (2). These same 3 countries, in addition to Iraq (EMR) and South Sudan (AFR), had the highest rates of internal displacement worldwide. Globally by the end of 2018 , the majority of returned refugees, internally displaced populations (IDPs) and asylum seekers were within or to Iraq, Pakistan, Sudan and Syrian Arab Republic (2).

These high rates of mobility have increased the need for access and utilization of health care services for and by these populations while on the move and within the countries where they are hosted. While flows of migrants for work purposes in the Region are dominated by men of working-age, those of refugees are predominantly children and young people and women of reproductive age. They also include elderly populations, with a resulting higher burden on the health system, particularly fragile systems $(3,4)$. With a variety of potential health needs among refugees and migrants, health systems need to 
be reformed to be able to offer migration-responsive services, and to tailor delivery to different contexts. A critical enabler of such responsiveness, however, is financing, and innovative financing solutions are needed to cover the associated costs (5).

Bozorgmehr et al. have noted that, globally, health research on these topics has tended to focus on individual migrants and their medical needs or on specific diseases (particularly infectious diseases and mental health) or subpopulations; this narrow focus, they argue, has constrained understanding of the links between policies, health system responses and health outcomes (6). This applies particularly in the EMR, where the health system aspects of receiving and providing health care for these large mobile populations with their specific health needs, as well as aspects of health care worker migration, are poorly understood. The countries of the EMR are only beginning to develop policies to address the health system implications of massive flows of people within and from outside their borders.

\section{Objectives and scope}

The aim of the paper is to review the available published literature critically and to identify gaps related to the health of migrants, refugees and IDPs in the EMR, based on the WHO 6 health system building blocks.

\section{Methods}

With the assistance of a library sciences specialist, a comprehensive literature search was conducted on health system aspects of the health of migrants, refugees and IDPs in the EMR. To be included in the review, articles needed to fulfil the following inclusion criteria: address one or more of the following populations: migrants, IDPs, refugees, expatriates, asylum seekers and migrating or displaced health care providers; focus on these populations residing in one of the EMR countries (Afghanistan, Bahrain, Djibouti, Egypt, Iraq, Islamic Republic of Iran, Jordan, Kuwait, Lebanon, Libya, Morocco, Oman, Pakistan, Qatar, Saudi Arabia, Somalia, Sudan, Syrian Arab Republic, Tunisia, United Arab Emirates and Yemen); and include discussion of access to health care and utilization of health services/facilities, including health-related policies, recommendations for improving health care or challenges for accessing health services for the population of interest; and use a clear study design (cross-sectional or observational studies, clinical trials, case-control etc.); and be published in any language. As noted, the scope specifically excludes literature on migrants or refugees from the EMR who are currently residing in other regions of the world and sources that solely addressed health needs (not health system-related issues) of the concerned populations. Publications that did not offer new data, such as commentaries, were excluded. Review papers were also excluded but their bibliographies were screened to guarantee the inclusion of all related publications.

\section{Results and discussion}

\section{Characteristics of the relevant published literature}

A total of 4679 journal publications published between 1946 and January 2019 were retrieved from searching MEDLINE and POPLINE databases. After screening titles and abstracts, 306 articles were included for full-text screening, out of which 140 (7-146) met the inclusion crii teria. An additional article was included by hand search bibliography (147). Also, 45 (148-192) articles were included after updating the MEDLINE search in December 2020. We were not able to update the POPLINE search due to its discontinuation in September 2019. Thus, a total of 186 published articles were included (Figure 1).

\section{The identified literature according to the health system building blocks}

Given the focus of the review on health systems and access to health services, the identified literature is presented according to each population of interest and the 6 WHO health system building blocks (the framework used for this analysis): service delivery; health workforce; information; medical products, vaccines and technologies; financing; and leadership and governance (193). Table 1 shows a quantitative summary of the distribution of articles that address issues related to the 6 health system building blocks. Service delivery $(n=47)$ is the topic that attracted the most research attention, followed by health workforce $(n=32)$ and the availability of medical products (including vaccines and technologies) $(n=28)$. While the majority of articles addressed refugee health followed by IDPs, very few studies pertaining to migrants were identified in relation to the 6 health system building blocks.

\section{Service delivery}

Around a third of the publications (34.1\%) addressed the delivery of services for refugees and IDPs (Table 1); none addressed service delivery for migrants. Thus this section will focus on the 2 populations: refugees and IDPs. For refugees, primary health care and sexual and reproductive health services were the most addressed in the literature. Primary health care services were considered the first line health facility in camps. Overall, they were reported to be available but not always free for refugees. Antenatal care and delivery services were reported to be available but several access barriers were also reported such as cost, absence of skilled birth attendants and transportation issues. However, postnatal care was reported to be mostly lacking and even if available, not sought due to lack of social support and cost barriers. Other services such as those related to noncommunicable diseases, infectious diseases, mental health and child health were less addressed; however, it was clear that health care for children seems to be a priority in service delivery. A similar picture emerges concerning service delivery on IDPs, but the litera- 


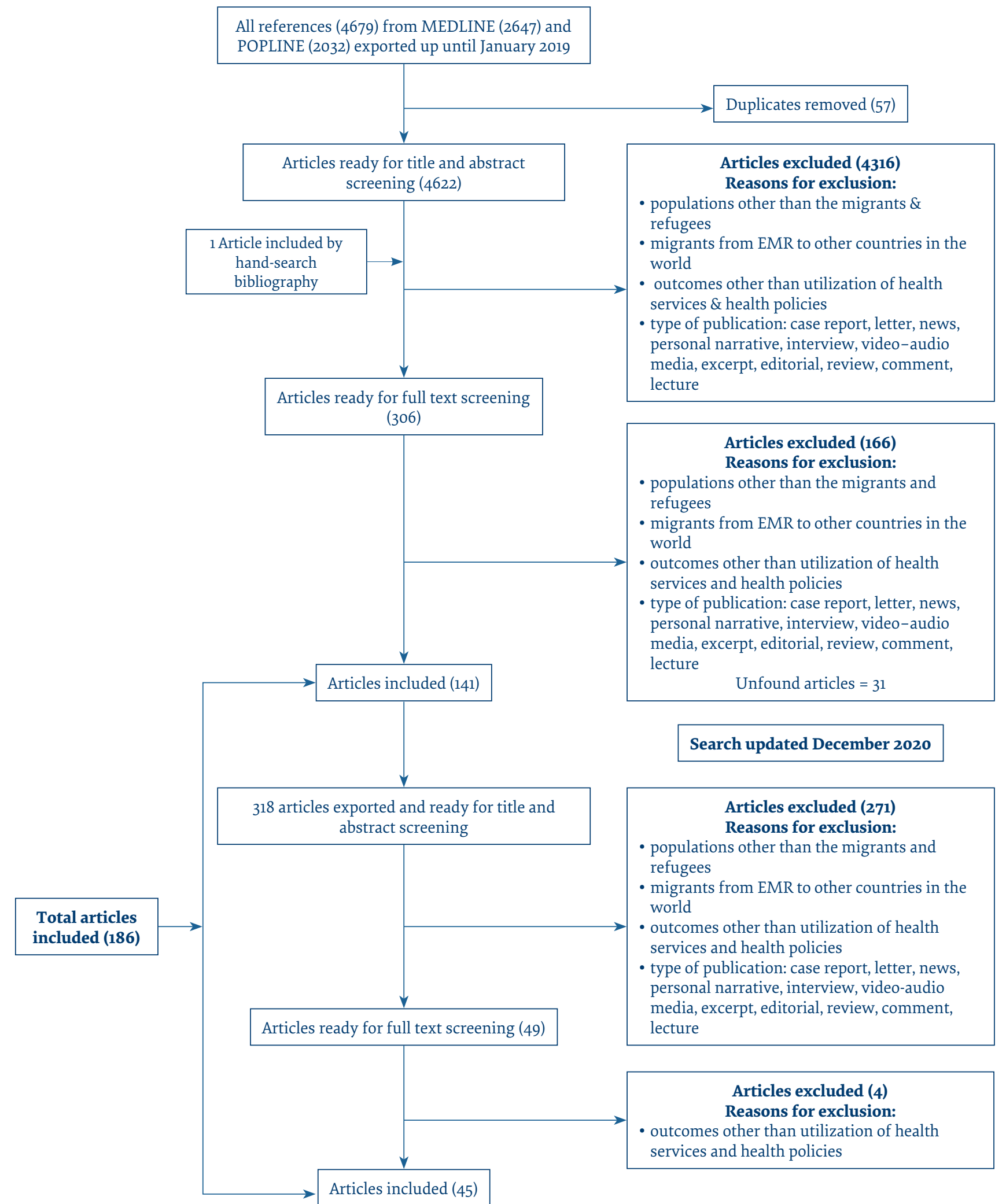

ture did not address services for IDPs as much as it did for refugees. Injury care (including treating the severely wounded, providing reconstructive surgeries and opening emergency rooms) was abundantly addressed in the literature, but reported as not always being available.
With funding shortfalls for the humanitarian response, particularly as crises in the Region are becoming protracted, there is a need for innovative and responsive service delivery models $(5,194)$. In order not to leave behind the hard-to-reach populations, there is also a need for mobile service delivery models; however, only 2 identified 


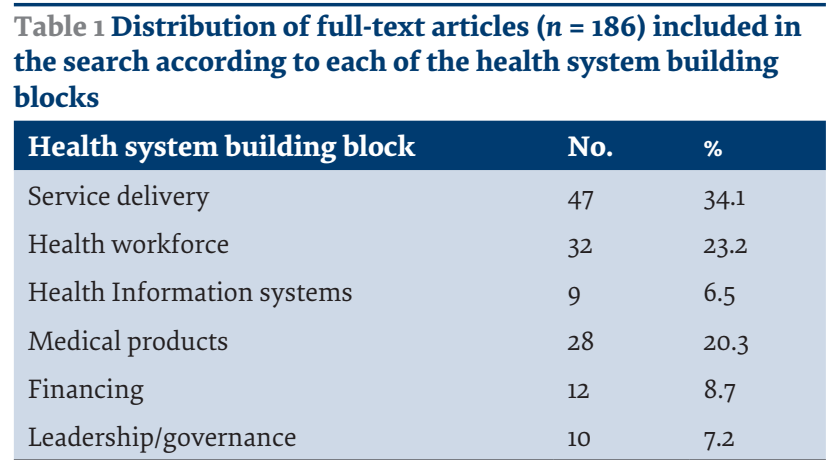

articles from the Region explored the potential of such delivery models or the potential of e-health for meeting the specific needs of mobile populations, who may lack awareness about available fixed services $(8,195)$. Studies are needed on the effectiveness of such interventions but also their potential for being scaled up.

Two recent studies measuring health care access and barriers to access, specifically among Syrian refugees, were conducted among nationally representative samples in Lebanon and Jordan $(39,196)$. In addition, only 2 studies addressed the needs of particular subgroups or vulnerable subpopulations among migrants or refugees; one was conducted in Lebanon assessing needs of the elderly subpopulation of Syrian refugees in Lebanon (12), while the second was in the Syrian Arab Republic looking at the health needs of the internally displaced and femaleheaded households (25). However, few identified studies from this review compared accessibility or utilization patterns across populations, comparing, for example, those of migrants and refugees to host populations. One exception is a study by Alnuaimi et al. in Jordan, which compared pregnancy outcomes among Syrian refugee and Jordanian women (31). Given the observed tensions between migrant and refugee populations on the one hand and host populations on the other during protracted crises in low- and middle-income countries with limited resources, redressing such differentials is critical.

Overall, out of 45 articles that reported on research about service delivery, the majority studied the responsiveness of health services to the needs of migrants, refugees and IDPs. A strikingly absent dimension in this literature on the health system building blocks is assessment of the quality of services offered to refugees and migrants and their perceptions of their experiences using the available services. One exception is a study of perceptions of reproductive health services provided to refugees in Yemen (107). Another study addressed perceived barriers to accessing health care among Syrian refugees in Jordan (40). A qualitative study addressed ethical challenges facing health care providers in Jordan to Syrian refugees when resources did not allow them to provide the evidence-based care they would strive to provide (192). And another study in Jordan included data collection with Syrian refugees about their priorities for health care as well as with providers, who reported the need for more emphasis on mental health and noncommunicable diseases (147).
Few of the identified studies address legal barriers to accessing services or the particular situation of undocumented migrants in the Region. This global topic was emphasized by Legido-Quigley et al. who considered that "health coverage cannot be described as universal if it excludes migrants, but many countries do so." (197) As countries develop plans for meeting the 2030 Sustainable Development Goals (SDGs) of "No one left behind," and specifically SDG 3 , target 8 , achieving universal health coverage, and SDG 10, target 7, focusing on wellmanaged migration policies, ensuring that migrants (including the undocumented) and refugees (including those unregistered) are included is essential. None of the identified studies addressed this challenge explicitly or tested approaches to doing so.

A key area of needed future work, although not sufficiently addressed in the available published literature, is the integration of refugees and migrants in plans for emergency preparedness. Two exceptions are an article by Wasay and Mustaq on health issues of IDPs in Pakistan and preparation for future disasters and an article by Delargy et al. on contingency planning and emergency preparedness for reproductive health in Iraq $(84,120)$. Qayum et al. also assess primary health care services in Pakistan according to SPHERE standards and indicators (73). Spiegel et al. argue that, globally, the predominant focus of humanitarian funding on postemergency assistance has meant that the potential for pre-emergency preparedness and risk sharing before emergencies occur has often been overlooked (5).

\section{Workforce}

This health system building block was addressed in 32 articles, which corresponds to $23.2 \%$ of the literature meeting inclusion criteria (Table 1). Migration or forced displacement of health care providers, including nurses, physicians and medical students from and within the EMR, was highlighted in 17 out of the 183 publications. Other workforce related topics were the lack of skilled birth attendance and not considering trans-cultural medical care issues such as the absence of midwives or female gynaecologists. Two articles focused on concerns about refugees and migrants (mainly male food-handlers and female domestic workers) who were considered potential vectors for transmitting microbial infections $(27,83)$.

A well-trained workforce with appropriate skills is required to respond to the health needs of migrants and refugees, particularly to overcome barriers in health care access. Typically, countries in conflict experience a brain drain of trained health care personnel $(71,78)$. Health care personnel are among the refugees fleeing to neighbouring countries, yet their training and qualifications may not be recognized in the new host countries and they are often not legally entitled to provide health care despite the evident need among refugee populations. In countries hosting refugees there may be a need for legislative change or special provisions, as has happened in some European countries, to allow continuous education and credentialing and ultimately to allow refugees to serve 
(as a minimum) the health needs of populations from the same countries. In Turkey, for example, Arabic-speaking Syrian doctors have been allowed to staff the migrant centres set up to meet the needs of predominantly Syrian refugees $(198,199)$.

The existing studies on health care worker migration identified in this review focused on the motivation for the migration, rather than the health system consequences of brain drain or strategies for retention. Moreover, these studies focused overwhelmingly on issues pertaining to medical personnel and much less on other categories of health workers. One exception is a study on community health workers and their role in trachoma control in a Somali refugee camp (142).

\section{Information}

Data on information systems addressing these populations were few (6.5\%) (Table 1); however, some successful examples were provided in terms of referral and tracking of patients, such as the Refugee Assistance Information System (RAIS), e-health at UNRWA's primary health care centres and various apps $(8,76,77)$. Other publications focused on the importance of having a well-structured e-system in order to track cases and referrals. In order to optimize the use of scarce resources in humanitarian contexts, it is essential to have a well-established health information system. However, basic data are often lacking in the EMR, particularly in countries experiencing conflict, on the population size of migrant and refugee populations, particularly of those not legally registered. There is no consensus as to how to measure migrant status appropriately and there are methodological and logistical challenges to collecting information on displaced populations, particularly undocumented migrants (197). There is, therefore, a lack of population-based data disaggregated by migration status, which makes it difficult, if not impossible, to assess the health needs of these groups. For the data that do exist, safeguarding confidentiality is particularly critical concerning refugees and migrants, with understandable fears among such populations as to how such data might be used.

Given the mobility of these populations and the frequent lack of established sampling frames which allow for drawing representative samples to assess health needs on a representative basis, it is challenging to conduct rigorous studies. Yet it is only with adequate and disaggregated information that governments and humanitarian actors, in collaboration with funders from international organizations, can intervene to address actual health needs. There is therefore an urgent need in the Region for well-designed information systems to analyse data separately between refugees, migrants and citizens in order to evaluate interventions and assess needs over time. Only 2 retrieved articles addressed this challenge, an article by Rossi et al. on the implementation of an information system for the Palestinian Red Crescent Society in Lebanon (92) and another on nurses' use of global information systems to offer reproductive health services to IDPs in Somalia (100).

\section{Medical products}

The proportion of studies on medical products and technologies $(20.3 \%)$ was similar to that on the health workforce. Unlike vaccines, medications for sexually transmitted infections, mental health and vitamins were reported to be rarely or not available at all for refugees and IDPs. Medications for noncommunicable diseases were variably offered depending on context, but were often reported as inaccessible due to cost or being out of stock. Equipment in health centres varied widely: some were well-equipped and others lacked basic necessities such as electricity. Only one study addressed the different vaccination strategies for migrants and refugees in the EMR countries (Egypt, Jordan and Tunisia) (23).

\section{Financing}

Financing was the third least addressed of the WHO health system building blocks (accounting for $8.7 \%$ of the literature) (Table 1). The main finance-related aspect mentioned was related to out-of-pocket payments for consultations, hospitalization and medication, although some international organizations such as WHO and nongovernmental organizations such as Médecins Sans Frontières were able to provide funding for vaccination for migrant and refugee populations.

Funding is a key constraint to ensuring access and utilization of health care services for refugee and migrant populations. High out-of-pocket expenditures on health care by these populations exacerbates existing poverty levels, especially given the restrictions on employment for refugees in the EMR. At the same time, low- and middleincome countries hosting refugees from neighbouring countries assume a major financial burden that has not been adequately offset by aid funds. As noted, there is a need for hosting governments and humanitarian agencies whose resources have been stretched by the volume of displacement and by the protracted nature of recent conflicts to develop and test innovative financing models so that they are able to provide more sustainable and effective health services to migrants, refugees and IDPs. However, only one article identified in this review addressed this challenge explicitly, although it has a global, not EMR, focus (5). Some countries of the EMR, such as the Islamic Republic of Iran, report having already succeeded in achieving universal health coverage and integrating legally documented refugees within their health system. Most EMR countries reported relying on UNHCR for refugees.

\section{Governance and leadership}

Though minimally addressed in the identified literature (7.2\%) (Table 1), the main concern singled out was the lack of leadership and well-conceptualized health policies for migrants and refugees. Lack of adequate governance and leadership in the health systems of countries experiencing major flows of refugees and migrants tends to lead to fragmentation of services and unclear lines of responsibility. Emergency preparedness and readiness are key issues when building a well-structured system by earmarking funds for emergency crises (200). Preparedness 
reduces the country's risk of health system fragmentation by preventing the creation of a parallel system that does not align with national strategies. This lack of system preparedness is perhaps one reason accounting for the peak in publications in 2014-2019, starting 3 years after the beginning of the Syrian crisis when the needs of refugees needed to be studied and priorities established. The formation of emergency multi-disciplinary teams which include health care providers, public health practitioners, political scientists, social workers, lawyers, information technology personnel and financing staff is a key means of preparing for emergencies as they would be responsible for dealing with problems arising inplace, improving what is available and suggesting longterm strategies (201). Moreover, governments and NGOs should benchmark the experiences of other countries to learn from successes and failures. One recent study employed the concept of "resilience" to analyse, through qualitative interviews with keys stakeholders, the "resilience" of the UNRWA health provision for Palestinian refugees in Lebanon, including its ability to weather adversity and tensions between refugees and host populations (191). Governments also need to address projected returnees to their home countries in their health strategy response. However, only one study (on Jordanian returnees from Kuwait) (123) addressed this issue, which will become more and more relevant as current conflicts in the Region ultimately come to a long-awaited conclusion.

\section{Conclusion}

This paper critically analysed the available literature on the entire EMR on health and migration from a health system perspective. It has identified areas of strength, but also major gaps in which there has been little research. As a region disproportionately affected by migration and forced displacement, it is important to take stock of the existing scientific knowledge in order to learn from experience. The ultimate aim is to support the admirable efforts of countries to cater for the health needs of those who live beyond their own countries of origin, whether by choice or due to humanitarian emergency. With migration becoming a major issue worldwide and the number of migrants and displaced persons increasing, the focus on migration-responsive health systems will benefit the general population and thus ultimately serve the needs of all if executed with quality standards.

Funding: We are grateful to the World Health Organization Regional Office for the Eastern Mediterranean for supporting this review of literature and facilitating its submission for publication. Additional support from the UK Research and Innovation as part of the Global Challenges Research Fund, grant number ES/Po10873/1 is also gratefully acknowledged.

Competing interests: None declared.

\section{Considérations des systèmes de santé relatives aux déplacements volontaires et forcés dans la Région de la Méditerranée orientale : analyse critique de la littérature disponible}

\section{Résumé}

Contexte : La Région OMS de la Méditerranée orientale présente depuis longtemps des schémas migratoires complexes, avec des niveaux élevés de migration vers la Région, en provenance et à l'intérieur de celle-ci, auxquels viennent s'ajouter les récents déplacements forcés en masse. Très peu d'informations sont disponibles sur la réponse des systèmes de santé à cette mobilité à grande échelle.

Objectifs : Effectuer une analyse critique de la littérature sur la Région, identifier les lacunes et suggérer les domaines nécessitant une attention particulière de la part des chercheurs et des responsables politiques.

Méthodes : Une recherche de la littérature publiée dans Medline et Popline a été effectuée dans le domaine de la santé et des migrations. Celle-ci se concentrait principalement sur les éléments constitutifs des systèmes de santé de l'OMS, sans limitation de date ni de langue.

Résultats : Sur 4679 articles récupérés, publiés entre 1964 et janvier 2019, 140 répondaient à nos critères d'inclusion ; 45 articles supplémentaires ont été inclus lors d'une mise à jour en décembre 2020. La plupart des publications portaient sur les réfugiés et la prestation de services.

Conclusion : Peu d'études examinaient la réactivité du système de santé face aux réfugiés et aux migrants, comparativement à celles menées pour les communautés d'accueil, ou évaluaient la qualité des services, ou encore s'intéressaient à la perception des réfugiés/migrants à l'égard des services de santé disponibles. Peu d'études suggéraient de nouvelles approches pour financer l'accès de ces populations aux soins de santé, ou de nouveaux mécanismes de gouvernance. 


\section{اعتبارات النظام الصحي المتعلقة بالنزوح الطوعي والقسري في إقليم شرق المتوسط: تحليل نقدي للمؤلفات المتاحة} إيـان شرارة، شذى عقيق، ميكايلا مارتيني، جوسيلين ديونج

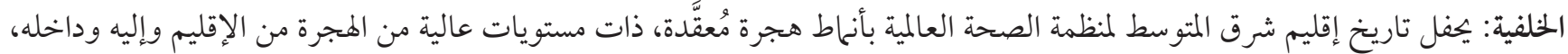

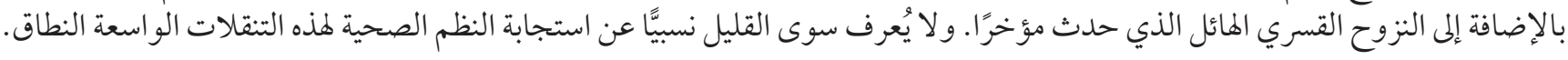
الأهداف: هدفت هذه الدراسة إلى استعر اض المؤلفات المنشورة بشأن الإقليم استعراضًا نقديًا، وتحديد الثغرات، واقتراح المجالات التي تحتاج إلى إلى اهتمام على صعيد البحوث: هدفت هده السياسات.

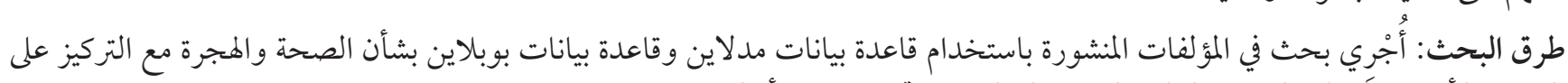

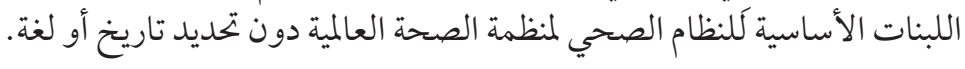

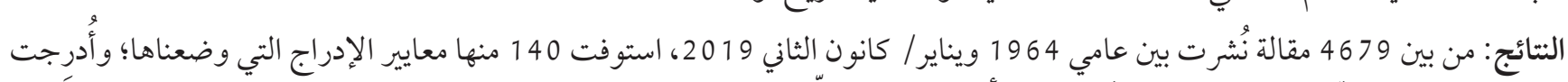

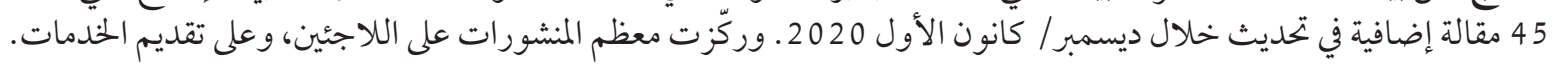

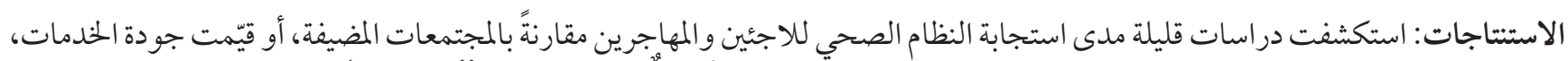

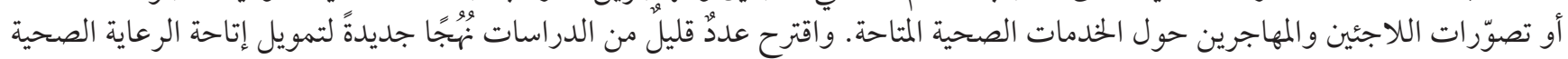

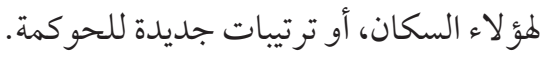

\section{References}

1. IOM world migration report 2020 [online]. Geneva: International Organization for Migration; 2020.

2. UNHCR Global trends - forced displacement in 2018. Geneva: UNHCR; 2019.

3. Update on UNHCR's operations the Middle East and North Africa, Standing Committee 77th meeting. Geneva: UNHCR, Executive Committee of the High Commissioner's Programme; 2020.

4. Labour migration. Geneva: International Labor Organization; 2020 (https://www.ilo.org/beirut/areasofwork/labour-migration/ lang--en/index.htm, accessed 23 September 2021).

5. Spiegel P, Chanis R, Trujillo A. Innovative health financing for refugees. BMC Med. 2018 Jun 15;16(1):90. doi:10.1186/s12916-0181068-9

6. Bozorgmehr K, Roberts B, Razum O, Biddle L, eds. Health policy and systems responses to forced migration, 1st ed. Cham: Springer International Publishing; 2020.

7. Zarocostas J. Libya: war and migration strain a broken health system. Lancet. 2018 Mar 3;391(10123):824-25. doi:10.1016/So1406736(18)30505-1 (Erratum in: Lancet. 2018 Mar 13)

8. Saleh S, Alameddine M, Farah A, El Arnaout N, Dimassi H, Muntaner C, El Morr C. eHealth as a facilitator of equitable access to primary healthcare: the case of caring for non-communicable diseases in rural and refugee settings in Lebanon. Int J Public Health. 2018 Jun;63(5):577-588. doi:10.1007/s00038-018-1092-8

9. Peak CM, Reilly AL, Azman AS, Buckee CO. Prolonging herd immunity to cholera via vaccination: accounting for human mobility and waning vaccine effects. PLoS Negl Trop Dis. 2018 Feb 28;12(2):e0006257. doi:10.1371/journal.pntd.0006257

10. Lilleston P, Winograd L, Ahmed S, Salamé D, Al Alam D, Stoebenau K, Michelis I, Palekar Joergensen S. Evaluation of a mobile approach to gender-based violence service delivery among Syrian refugees in Lebanon. Health Policy Plan. 2018 Sep 1;33(7):767776. doi:10.1093/heapol/czyo50

11. Lafta R, Al-Ani W, Dhiaa S, Cherewick M, Hagopian A, Burnham G. Perceptions, experiences and expectations of Iraqi medical students. BMC Med Educ. 2018 Mar 27;18(1):53. doi:10.1186/s12909-018-1156-8

12. Chemali Z, Borba CPC, Johnson K, Khair S, Fricchione GL. Needs assessment with elder Syrian refugees in Lebanon: Implications for services and interventions. Glob Public Health. 2018 Sep;13(9):1216-1228. doi:10.1080/17441692.2017.1373838

13. Asadi H, Ahmadi B, Nejat S, Akbari Sari A, Garavand A, et al. Factors influencing the migration of Iranian healthcare professionals: a qualitative study. PLoS One. 2018 Jun 27;13(6):e0199613. doi:10.1371/journal.pone.0199613

14. Llosa AE, Van Ommeren M, Kolappa K, Ghantous Z, Souza R, Bastin P, Slavuckij A, Grais RF. A two-phase approach for the identification of refugees with priority need for mental health care in Lebanon: a validation study. BMC Psychiatry. 2017 Jan 18;17(1):28. doi:10.1186/s12888-016-1154-5

15. Tappis H, Lyles E, Burton A; Jordan Health Access Study Team; Lebanon Health Access Study Team, Doocy S. Maternal health care utilization among Syrian refugees in Lebanon and Jordan. Matern Child Health J. 2017 Sep;21(9):1798-1807. doi:10.1007/ s10995-017-2315-y 
16. Simon B, Sow F, Al Mukhaini SK, Al-Abri S, Ali OAM, Bonnot G, et al. An outbreak of locally acquired Plasmodium vivax malaria among migrant workers in Oman. Parasite. 2017;24:25. doi:10.1051/parasite/2017028

17. Shah SM, Ali R, Loney T, Aziz F, ElBarazi I, Al Dhaheri S, et al. Prevalence of diabetes among migrant women and duration of residence in the United Arab Emirates: a cross sectional study. PLoS One. 2017 Jan 18;12(1):e0169949. doi:10.1371/journal.pone.o169949

18. Sethi S, Jonsson R, Skaff R, Tyler F. Community-based noncommunicable disease care for Syrian refugees in Lebanon. Glob Health Sci Pract. 2017 Sep 28;5(3):495-506. doi:10.9745/GHSP-D-17-00043

19. Schulman-Marcus J, Heo R, Gransar H, Suwaidi JA, Alkuwari M, Elmore K, et al. Subclinical atherosclerosis detected by coronary computed tomographic angiography in Qatar: a comparison between Qataris and south Asian migrants. Int J Cardiovasc Imaging. 2017 Jun;33(6):927-935. doi:10.1007/s10554-017-1073-7

20. Sami S, Kerber K, Kenyi S, Amsalu R, Tomczyk B, Jackson D, et al. State of newborn care in South Sudan' WHO health system building blocks s displacement camps: a descriptive study of facility-based deliveries. Reprod Health. 2017 Nov 29;14(1):161. doi:10.1186/s12978-017-0417-Z

21. Kazour F, Zahreddine NR, Maragel MG, Almustafa MA, Soufia M, Haddad R, et al. Post-traumatic stress disorder in a sample of Syrian refugees in Lebanon. Compr Psychiatry. 2017 Jan;72:41-47. doi:10.1016/j.comppsych.2016.09.007

22. Honarvar B, Moghadami M, Lankarani KB, Davarpanah MA, Ataolahi M, Farbod A, et al. Brucellosis as a neglected disease in a neglected population: a seroepidemiological study of migratory nomads in the Fars province of Iran. Epidemiol Infect. 2017 Feb;145(3):491-497. doi:10.1017/So950268816002600

23. Giambi C, Del Manso M, Dente MG, Napoli C, Montaño-Remacha C, Riccardo F, et al. Immunization strategies targeting newly arrived migrants in non-EU countries of the Mediterranean Basin and Black Sea. Int J Environ Res Public Health. 2017 Apr 25;14(5):459. doi:10.3390/ijerph14050459

24. Etemadifar M, Sadeghpour N, Nekouie K, Jahansouz M, Salari M, Fereidan-Esfahani M. Multiple sclerosis among Afghan immigrants in Isfahan, Iran. Mult Scler Relat Disord. 2017 Apr;13:52-57. doi:10.1016/j.msard.2017.02.006

25. Doocy S, Lyles E. Humanitarian needs among displaced and female-headed households in government-controlled areas of Syria. Am J Public Health. 2017 Jun;107(6):950-959. doi:10.2105/AJPH.2017.303710

26. Daher A, Alabbadi I. Investigating the effect of Syrian refugees on the pharmaceutical sector in Jordan. Arch Iran Med. 2017 Aug;20(8):538-546. PMID:28846018

27. Dafalla AIA, Almuhairi SASO, AlHosani MHJ, Mohamed MY, Alkous MIA, AlAzzawi MA, et al. Intestinal parasitic infections among expatriate workers in various occupations in Sharjah, United Arab Emirates. Rev Inst Med Trop Sao Paulo. 2017 Dec 21;59:e82. doi:10.1590/S1678-9946201759082

28. Azman AS, Bouhenia M, Iyer AS, Rumunu J, Laku RL, Wamala JF, et al. High hepatitis E seroprevalence among displaced persons in South Sudan. Am J Trop Med Hyg. 2017 Jun;96(6):1296-1301. doi:10.4269/ajtmh.16-0620

29. Amin, K, Seita A. Health and status of Palestine refugees from Syria in Jordan: situational analysis. Final report. Boston: John Snow Inc.; 2017:21.

30. Al-Smadi AM, Tawalbeh LI, Gammoh OS, Ashour AF, Alshraifeen A, Gougazeh YM. Anxiety, stress, and quality of life among Iraqi refugees in Jordan: a cross sectional survey. Nurs Health Sci. 2017 Mar;19(1):100-104. doi:10.1111/nhs.12323

31. Alnuaimi K, Kassab M, Ali R, Mohammad K, Shattnawi K. Pregnancy outcomes among Syrian refugee and Jordanian women: a comparative study. Int Nurs Rev. 2017 Dec;64(4):584-592. doi:10.1111/inr.12382

32. West L, Isotta-Day H, Ba-Break M, Morgan R. Factors in use of family planning services by Syrian women in a refugee camp in Jordan. J Fam Plann Reprod Health Care. 2016 Apr 11;73(2):96-102. doi:10.1136/jfprhc-2014-101026

33. Wahid S, Stresman GH, Kamal SS, Sepulveda N, Kleinschmidt I, Bousema T, et al. Heterogeneous malaria transmission in longterm Afghan refugee populations: a cross-sectional study in five refugee camps in northern Pakistan. Malar J. 2016 Apr 27;15:245. doi:10.1186/s12936-016-1305-7

34. Naja WJ, Aoun MP, El Khoury EL, Abdallah FJ, Haddad RS. Prevalence of depression in Syrian refugees and the influence of religiosity. Compr Psychiatry. 2016 Jul;68:78-85. doi:10.1016/j.comppsych.2016.04.002

35. Nadim W, AlOtaibi A, Al-Mohaimeed A, Ewid M, Sarhandi M, Saquib J, et al. Depression among migrant workers in Al-Qassim, Saudi Arabia. J Affect Disord. 2016 Dec;206:103-108. doi:10.1016/j.jad.2016.07.037

36. Hossain N, Shah N, Shah T, Lateef SB. Physicians' migration: perceptions of Pakistani medical students. J Coll Physicians Surg Pak. 2016 Aug;26(8):696-701. PMID:27539766

37. Doocy S, Lyles E, Akhu-Zaheya L, Oweis A, Al Ward N, Burton A. Health service utilization among Syrian refugees with chronic health conditions in Jordan. PLoS One. 2016 Apr 13;11(4):e0150088. doi:10.1371/journal.pone.0150088

38. Doocy S, Lyles E, Akhu-Zaheya L, Burton A, Weiss W. Health service utilization and access to medicines among Syrian refugee children in Jordan. Int J Health Plann Manage. 2016 Jan-Mar;31(1):97-112. doi:10.1002/hpm.2336

39. Doocy S, Lyles E, Akhu-Zaheya L, Burton A, Burnham G. Health service access and utilization among Syrian refugees in Jordan. Int J Equity Health. 2016 Jul 14;15(1):108. doi:10.1186/s12939-016-0399-4

40. Ay M, Arcos González P, Castro Delgado R. The perceived barriers of access to health care among a group of non-camp Syrian refugees in Jordan. Int J Health Serv. 2016 Jul;46(3):566-89. doi:10.1177/0020731416636831 
41. Ammar W, Kdouh O, Hammoud R, Hamadeh R, Harb H, Ammar Z, et al. Health system resilience: Lebanon and the Syrian refugee crisis. J Glob Health. 2016 Dec;6(2):020704. doi:10.7189/jogh.06.020704

42. Abu-Madi MA, Behnke JM, Boughattas S, Al-Thani A, Doiphode SH. A decade of intestinal protozoan epidemiology among settled immigrants in Qatar. BMC Infect Dis. 2016 Aug 5;16:370. doi:10.1186/s12879-016-1728-3

43. Shah SM, Loney T, Sheek-Hussein M, El Sadig M, Al Dhaheri S, El Barazi I, et al. Hypertension prevalence, awareness, treatment, and control, in male South Asian immigrants in the United Arab Emirates: a cross-sectional study. BMC Cardiovasc Disord. 2015 May 7;15:30. doi:10.1186/s12872-015-0024-2

44. Salah TT, Ayazi T, Lien L, Eide A, Hauff E. Social phobia among long-term internally displaced persons: an epidemiological study of adults in two internally displaced person settlements in Sudan. Int J Soc Psychiatry. 2015 Sep;61(6):550-9. doi:10.1177/0020764014564800

45. Mujeeb A. Mental health of internally displaced persons in Jalozai camp, Pakistan. Int J Soc Psychiatry. 2015 Nov;61(7):653-9. doi:10.1177/0020764015573083

46. Gammouh OS, Al-Smadi AM, Tawalbeh LI, Khoury LS. Chronic diseases, lack of medications, and depression among Syrian refugees in Jordan, 2013-2014. Prev Chronic Dis. 2015 Jan 29;12:E10. doi:10.5888/pcd12.140424

47. Fouad YA, Fahmy YM, Abdel Hady SM, Elsabagh AE. Egyptian future physicians are packing to leave but may be willing to return. Int Health. 2015 May;7(3):190-4. doi:10.1093/inthealth/ihu072

48. Elhabiby MM, Radwan DN, Okasha TA, El-Desouky ED. Psychiatric disorders among a sample of internally displaced persons in South Darfur. Int J Soc Psychiatry. 2015 Jun;61(4):358-62. doi:10.1177/0020764014547061

49. Doocy S, Lyles E, Roberton T, Akhu-Zaheya L, Oweis A, Burnham G. Prevalence and care-seeking for chronic diseases among Syrian refugees in Jordan. BMC Public Health. 2015 Oct 31;15:1097. doi:10.1186/s12889-015-2429-3

50. Bouchghoul H, Hornez E, Duval-Arnould X, Philippe HJ, Nizard J. Humanitarian obstetric care for refugees of the Syrian war. The first 6 months of experience of Gynécologie Sans Frontières in Zaatari Refugee Camp (Jordan). Acta Obstet Gynecol Scand. 2015 Jul;94(7):755-759. doi:10.1111/aogs.12638

51. Amiri R, Heydari A, Dehghan-Nayeri N, Vedadhir AA, Kareshki H. Challenges of transcultural caring among health workers in mashhad-iran: a qualitative study. Glob J Health Sci. 2015 Dec 18;8(7):203-11. doi:10.5539/gjhs.v8n7p203

52. Al-Nawafleh AH. Managing Jordanian nurse migration to the Gulf Cooperation Council states. East Mediterr Health J. 2015 May 19;21(3):220-5. doi:10.26719/2015.21.3.220

53. Ahmed W, Ahmad M; Rafatullah, Shah F; Sajadullah. Pervasiveness of intestinal protozoan and worm incursion in IDP's (North Waziristan agency, KPK-Pakistan) children of 6-16 years. J Pak Med Assoc. 2015 Sep;65(9):943-5. PMID:26338737

54. Abrar Ul Haq K, Gul NA, Hammad HM, Bibi Y, Bibi A, Mohsan J. Prevalence of Giardia intestinalis and Hymenolepis nana in Afghan refugee population of Mianwali district, Pakistan. Afr Health Sci. 2015 Jun;15(2):394-400. doi:10.4314/ahs.v15i2.12

55. Reese Masterson A, Usta J, Gupta J, Ettinger AS. Assessment of reproductive health and violence against women among displaced Syrians in Lebanon. BMC Womens Health. 2014 Feb 20;14(1):25. doi:10.1186/1472-6874-14-25

56. Pasalar M, Mehrabani D, Afrasiabi A, Mehravar Z, Reyhani I, Hamidi R, Karimi M. Prevalence of thalassaemia, iron-deficiency anaemia and glucose-6-phosphate dehydrogenase deficiency among Arab migrating nomad children, southern Islamic Republic of Iran. East Mediterr Health J. 2014 Dec 17;20(11):726-31. PMID:25601811

57. Llosa AE, Ghantous Z, Souza R, Forgione F, Bastin P, Jones A, Antierens A, Slavuckij A, Grais RF. Mental disorders, disability and treatment gap in a protracted refugee setting. Br J Psychiatry. 2014 Mar;204(3):208-13. doi:10.1192/bjp.bp.112.120535

58. Khader A, Farajallah L, Shahin Y, Hababeh M, Abu-Zayed I, Zachariah R, et al. Hypertension and treatment outcomes in Palestine refugees in United Nations Relief and Works Agency primary health care clinics in Jordan. Trop Med Int Health. 2014 Oct;19(10):1276-83. doi:10.1111/tmi.12356

59. Khader A, Ballout G, Shahin Y, Hababeh M, Farajallah L, Zeidan W, et al. Treatment outcomes in a cohort of Palestine refugees with diabetes mellitus followed through use of E-Health over 3 years in Jordan. Trop Med Int Health. 2014 Feb;19(2):219-23. doi:10.1111/tmi.12241

6o. Khader A, Ballout G, Shahin Y, Hababeh M, Farajallah L, Zeidan W, et al. What happens to Palestine refugees with diabetes mellitus in a primary healthcare centre in Jordan who fail to attend a quarterly clinic appointment? Trop Med Int Health. 2014 Mar;19(3):308-312. doi:10.1111/tmi.12256

61. Janahi EM. Prevalence and risk factors of hepatitis B virus infection in Bahrain, 2000 through 2010. PLoS One. 2014 Feb 3;9(2):e87599. doi:10.1371/journal.pone.0087599

62. 6 Huster KM, Patterson N, Schilperoord M, Spiegel P. Cesarean sections among Syrian refugees in Lebanon from december 2012/january 2013 to june 2013: probable causes and recommendations. Yale J Biol Med. 2014 Sep 3;87(3):269-88. PMID:25191143

63. Honarvar B, Odoomi N, Rezaei A, Haghighi HB, Karimi M, Hosseini A, et al. Pulmonary tuberculosis in migratory nomadic populations: the missing link in Iran's National Tuberculosis Programme. Int J Tuberc Lung Dis. 2014 Mar;18(3):272-6. doi:10.5588/ ijtld.13.0650

64. Oral cholera vaccine campaign among internally displaced persons in South Sudan. Wkly Epidemiol Rec. 2014 May 16;89(20):214-20. PMID:24864347 
65. Akhtar S, Alroughani R, Al-Shammari A, Al-Abkal J, Ayad Y. Non-parametric analysis of seasonality in birth and multiple sclerosis risk in second generation of migrants in Kuwait. BMC Neurol. 2014 Aug 26;14:170. doi:10.1186/s12883-014-0170-7

66. Taha HA, Soliman MI, Banjar SA. Intestinal parasitic infections among expatriate workers in Al-Madina Al-Munawarah, Kingdom of Saudi Arabia. Trop Biomed. 2013 Mar;30(1):78-88. PMID:23665711

67. Salah TT, Abdelrahman A, Lien L, Eide AH, Martinez P, Hauff E. The mental health of internally displaced persons: an epidemiological study of adults in two settlements in Central Sudan. Int J Soc Psychiatry. 2013 Dec;59(8):782-8. doi:10.1177/0020764012456810

68. Elhag WI, Saeed HA, Omer el FE, Ali AS. Prevalence of rotavirus and adenovirus associated with diarrhea among displaced communities in Khartoum, Sudan. BMC Infect Dis. 2013 May 8;13:209. doi:10.1186/1471-2334-13-209

69. Doocy S, Sirois A, Tileva M, Storey JD, Burnham G. Chronic disease and disability among Iraqi populations displaced in Jordan and Syria. Int J Health Plann Manage. 2013 Jan-Mar;28(1):e1-e12. doi:10.1002/hpm.2119

70. Al-Khalisi N. The Iraqi medical brain drain: a cross-sectional study. Int J Health Serv. 2013;43(2):363-78. doi:10.2190/HS.43.2.j

71. Abu-Madi MA, Behnke JM, Doiphode SH. Intestinal parasitic infections among long-term-residents and settled immigrants in Qatar in the period 2005 to 2011. Am J Trop Med Hyg. 2013 Jun;88(6):1185-95. doi:10.4269/ajtmh.13-0006

72. Qayum M, Zahur H, Ahmad N, Ilyas M, Khan A, Khan S. SPHERE-based assessment of knowledge and preventive measures related to malaria among the displaced population of Jalozai, Pakistan. J Pak Med Assoc. 2012 Apr;62(4):344-6. PMID:22755277

73. Otoukesh S, Mojtahedzadeh M, Sherzai D, Behazin A, Bazargan-Hejazi S, Bazargan M. A retrospective study of demographic parameters and major health referrals among Afghan refugees in Iran. Int J Equity Health. 2012 Dec 20;11:82. doi:10.1186/14759276-11-82

74. Mateen FJ, Carone M, Nyce S, Ghosn J, Mutuerandu T, Al-Saedy H, et al. Neurological disorders in Iraqi refugees in Jordan: data from the United Nations Refugee Assistance Information System. J Neurol. 2012 Apr;259(4):694-701. doi:10.1007/s00415-0116248-x

75. Mateen FJ, Carone M, Al-Saedy H, Nyce S, Ghosn J, Mutuerandu T, et al. Medical conditions among Iraqi refugees in Jordan: data from the United Nations Refugee Assistance Information System. Bull World Health Organ. 2012 Jun 1;90(6):444-51. doi:10.2471/BLT.11.097048

76. Khader A, Farajallah L, Shahin Y, Hababeh M, Abu-Zayed I, Kochi A, et al. Cohort monitoring of persons with diabetes mellitus in a primary healthcare clinic for Palestine refugees in Jordan. Trop Med Int Health. 2012 Dec;17(12):1569-76. doi:10.1111/j.13653156.2012.03097.x

77. Burnham G, Malik S, Al-Shibli AS, Mahjoub AR, Baqer AQ, Baqer ZQ, et al. Understanding the impact of conflict on health services in Iraq: information from 401 Iraqi refugee doctors in Jordan. Int J Health Plann Manage. 2012 Jan-Mar;27(1):e51-64. doi:10.1002/hpm.1091

78. Badri A, Crutzen R, Van den Borne HW. Exposures to war-related traumatic events and post-traumatic stress disorder symptoms among displaced Darfuri female university students: an exploratory study. BMC Public Health. 2012 Aug 3;12:603. doi:10.1186/1471-2458-12-603

79. Qayum M, Anwar S, Raza UA, Qayum E, Qayum N, Qayum F. Assessment of health services on relevant primary health care principles in internally displaced people of pakistan based on sphere standards and indicators. J Coll Physicians Surg Pak. 2011 May;21(5):315-6. PMID:21575546

8o. Jabbari H, Sharifi AH, SeyedAlinaghi S, Kheirandish P, Sedaghat A, Sargolzaei M, Djavid GE, Khanbabae A, Rasoolinejad M, Mohraz M, McFarland W. Assessing the prevalence of HIV among Afghan immigrants in Iran through rapid HIV testing in the field. Acta Med Iran. 2011;49(7):478-9. PMID:21960083

81. Bile KM, Hafeez A, Kazi GN, Southall D. Protecting the right to health of internally displaced mothers and children: the imperative of inter-cluster coordination for translating best practices into effective participatory action. East Mediterr Health J. 2011 Dec;17(12):981-9. doi:10.26719/2011.17.12.981

82. Abu-Madi MA, Behnke JM, Ismail A, Al-Olaqi N, Al-Zaher K, El-Ibrahim R. Comparison of intestinal parasitic infection in newly arrived and resident workers in Qatar. Parasit Vectors. 2011 Nov 4;4:211. doi:10.1186/1756-3305-4-211

83. Wasay M, Mushtaq K. Health issues of internally displaced persons in Pakistan: preparation for disasters in future. Am J Disaster Med. 2010 Mar-Apr;5(2):126-8. PMID:20496645

84. Mousa HS, Yousef S, Riccardo F, Zeidan W, Sabatinelli G. Hyperglycaemia, hypertension and their risk factors among Palestine refugees served by UNRWA. East Mediterr Health J. 2010 Jun;16(6):609-14. PMID:20799587

85. Makki SM, Arafa WA. Parasitosis among apparently healthy immigrant workers at Dammam, Saudi Arabia. J Egypt Soc Parasitol. 2010 Aug;40(2):311-20. PMID:21246939

86. Ibrahim WH, Rasul KI, Khinji A, Ahmed MS, Bener A. Clinical and epidemiological characteristics of lung cancer cases in Qatar. East Mediterr Health J. 2010 Feb;16(2):166-70. PMID:20799569

87. Hamid AA, Musa SA. Mental health problems among internally displaced persons in Darfur. Int J Psychol. 2010 Aug 1;45(4):27885. doi:10.1080/00207591003692620

88. Chan EY, Kim JJ. Characteristics and health outcomes of internally displaced population in unofficial rural self-settled camps after the 2005 Kashmir, Pakistan earthquake. Eur J Emerg Med. 2010 Jun;17(3):136-41. doi:10.1097/MEJ.obo13e32832fcalc 
89. Basseri HR, Raeisi A, Holakouie K, Shanadeh K. Malaria prevention among Afghani refugees in a malarious area, southeastern Iran. Bull Soc Pathol Exot. 2010 Dec;103(5):340-5. doi:10.1007/s13149-010-0050-3

90. Balsara ZP, Wu I, Marsh DR, Ihsan AT, Nazir R, Owoso E, Robinson C, Darmstadt GL. Reproductive tract disorders among Afghan refugee women attending health clinics in Haripur, Pakistan. J Health Popul Nutr. 2010 Oct;28(5):501-8. doi:10.3329/jhpn. v28i5.6159

91. Rossi L, Materia E, Hourani A, Yousef H, Racalbuto V, Venier C, et al. Design and implementation of a hospital information system for the Palestine Red Crescent Society in Lebanon. East Mediterr Health J. 2009 May-Jun;15(3):738-46. PMID:19731791

92. Parvaresh N, Bahramnezhad A. Post-traumatic stress disorder in bam-survived students who immigrated to Kerman, four months after the earthquake. Arch Iran Med. 2009 May;12(3):244-9. PMID:19400601

93. Mostaghni A, Mehrabani D, Khademolhosseini F, Masoumi SJ, Moradi F, Zare N, et al. Prevalence and risk factors of gastroesophageal reflux disease in Qashqai migrating nomads, southern Iran. World J Gastroenterol. 2009 Feb 28;15(8):961-5. doi:10.3748/wjg.15.961

94. Chynoweth S. Williams Prince A. Progress and gaps: reproductive health among Iraqi refugee women and youth in Jordan: follow-up report. New York: Women's Refugee Commission; 2009:5.

95. Burnham GM, Lafta R, Doocy S. Doctors leaving 12 tertiary hospitals in Iraq, 2004-2007. Soc Sci Med. 2009 Jul;69(2):172-7. doi:10.1016/j.socscimed.2009.05.021

96. Bader F, Sinha R, Leigh J, Goyal N, Andrews A, Valeeva N, Sirois A, Doocy S; IMC Study Team. Psychosocial health in displaced Iraqi care-seekers in non-governmental organization clinics in Amman, Jordan: an unmet need. Prehosp Disaster Med. 2009 JulAug;24(4):312-20. doi:10.1017/s1049023x00007032

97. Alzahrani AJ, Obeid OE, Al-Ali A, Imamwardi B. Detection of Hepatitis C virus and Human immunodeficiency virus in expatriates in Saudi Arabia by antigen-antibody combination assays. J Infect Dev Ctries. 2009 Apr 30;3(3):235-8. doi:10.3855/jidc.42

98. Sinha R, Goyal N, Sirois A, Valeeva N, Doocy S. Family planning in displaced populations: an unmet need among Iraqis in Amman, Jordan. Am J Disaster Med. 2008 Sep-Oct;3(5):295-300. PMID:19069033

99. Shaikh MA. Nurses' use of global information systems for provision of outreach reproductive health services to internally displaced persons. Prehosp Disaster Med. 2008 May-Jun;23(3):S35-8. PMID:18702286

100. Furuta M, Mori R. Factors affecting women's health-related behaviors and safe motherhood: a qualitative study from a refugee camp in eastern Sudan. Health Care Women Int. 2008 Sep;29(8):884-905. doi:10.1080/07399330802269600

101. Chynoweth SK. The need for priority reproductive health services for displaced Iraqi women and girls. Reprod Health Matters. 2008 May;16(31):93-102. doi:10.1016/So968-8080(08)31348-2

102. Akhtar S, Mohammad HG. Seasonality in pulmonary tuberculosis among migrant workers entering Kuwait. BMC Infect Dis. 2008 Jan 7;8:3. doi:10.1186/1471-2334-8-3

103. Akhtar S, Mohammad HG. Spectral analysis of HIV seropositivity among migrant workers entering Kuwait. BMC Infect Dis. 2008 Mar 25;8:37. doi:10.1186/1471-2334-8-37

104. Aghasadeghi K, Zarei-Nezhad M, Keshavarzi A, Mehrabani D. The prevalence of coronary risk factors in Iranian lor migrating tribe. Arch Iran Med. 2008 May;11(3):322-5. PMID:18426325

105. Zeidan Z, Hashim K, Muhit MA, Gilbert C. Prevalence and causes of childhood blindness in camps for displaced persons in Khartoum: results of a household survey. East Mediterr Health J. 2007 May-Jun;13(3):580-5. PMID:17687831

106. Whelan A, Blogg J. 'Halfway people': refugee views of reproductive health services. Glob Public Health. 2007;2(4):373-94. doi:10.1080/17441690701267048

107. Morgos D, Worden JW, Gupta L. Psychosocial effects of war experiences among displaced children in southern Darfur. Omega (Westport). 2007-2008;56(3):229-53. doi:10.2190/om.56.3.b

108. Kim G, Torbay R, Lawry L. Basic health, women's health, and mental health among internally displaced persons in Nyala Province, South Darfur, Sudan. Am J Public Health. 2007 Feb;97(2):353-61. doi:10.2105/AJPH.2005.073635

109. Kadivar MR, Ghaneh-Shirazi R, Khavandegaran F, Karimi M. Epidemiology of tuberculosis among Afghan immigrants in Fars province, southern Islamic Republic of Iran. East Mediterr Health J. 2007 Jul-Aug;13(4):758-64. PMID:17955756

110. Esteghamati A, Gouya MM, Zahraei SM, Dadras MN, Rashidi A, Mahoney F. Progress in measles and rubella elimination in Iran. Pediatr Infect Dis J. 2007 Dec;26(12):1137-41. doi:10.1097/INF.obo13e3181462090

111. Akl EA, Maroun N, Major S, Afif C, Chahoud B, Choucair J, et al. Why are you draining your brain? Factors underlying decisions of graduating Lebanese medical students to migrate. Soc Sci Med. 2007 Mar;64(6):1278-84. doi:10.1016/j.socscimed.2006.10.021

112. Quddus A, Luby SP, Jamal Z, Jafar T. Prevalence of hepatitis B among Afghan refugees living in Balochistan, Pakistan. Int J Infect Dis. 2006 May;10(3):242-7. doi:10.1016/j.ijid.2005.04.007

113. Boccia D, Guthmann JP, Klovstad H, Hamid N, Tatay M, Ciglenecki I, et al. High mortality associated with an outbreak of hepatitis E among displaced persons in Darfur, Sudan. Clin Infect Dis. 2006 Jun 15;42(12):1679-84. doi:10.1086/504322

114. Sugerman DE, Hyder AA, Nasir K. Child and young adult injuries among long-term Afghan refugees. Int J Inj Contr Saf Promot. 2005 Sep;12(3):177-82. doi:10.1080/15660970500036481 
115. Izutsu T, Tsutsumi A, Sato T, Naqibullah Z, Wakai S, Kurita H. Nutritional and mental health status of Afghan refugee children in Peshawar, Pakistan: a descriptive study. Asia Pac J Public Health. 2005;17(2):93-8. doi:10.1177/101053950501700206

116. Bøhler M, Mustafaa SA, Mørkve O. Tuberculosis treatment outcome and health services: a comparison of displaced and settled population groups in Khartoum, Sudan. Int J Tuberc Lung Dis. 2005 Jan;9(1):32-6. PMID:15675547

117. Abal AT, Jayakrishnan B, Parwer S, El Shamy AS, Khadadah M, Ayed A, Al Alawi A. Demographic pattern and clinical characteristics of patients with smear- positive pulmonary tuberculosis in kuwait. Med Princ Pract. 2005 Sep-Oct;14(5):306-12. doi:10.1159/000086927

118. Kolaczinski J, Brooker S, Reyburn H, Rowland M. Epidemiology of anthroponotic cutaneous leishmaniasis in Afghan refugee camps in northwest Pakistan. Trans R Soc Trop Med Hyg. 2004 Jun;98(6):373-8. doi:10.1016/j.trstmh.2003.11.003

119. DeLargy P, Alakbarov R. Thinking ahead about reproductive health: contingency planning and emergency preparedness in crisis situations (Iraq and West Africa). Disasters. 2004 Sep;28(3):340-50. doi:10.1111/j.0361-3666.2004.00262.x

120. Brooker S, Mohammed N, Adil K, Agha S, Reithinger R, Rowland M, Aet al. Leishmaniasis in refugee and local Pakistani populations. Emerg Infect Dis. 2004 Sep;10(9):1681-4. doi:10.3201/eid1009.040179

121. Rahman A, Hafeez A. Suicidal feelings run high among mothers in refugee camps: a cross-sectional survey. Acta Psychiatr Scand. 2003 Nov;108(5):392-3. doi:10.1034/j.1600-0447.2003.00220.x

122. Jaddou HY. Psychiatric disorders among adolescent Jordanian returnees from Kuwait during the 1991 Gulf War. East Mediterr Health J. 2003 Jan-Mar;9(1-2):20-7. PMID:15562729

123. Kalafi Y, Hagh-Shenas H, Ostovar A. Mental health among Afghan refugees settled in Shiraz, Iran. Psychol Rep. 2002 Feb;90(1):262-6. doi:10.2466/pro.2002.90.1.262

124. Shah I, Rowland M, Mehmood P, Mujahid C, Razique F, Hewitt S, et al. Chloroquine resistance in Pakistan and the upsurge of falciparum malaria in Pakistani and Afghan refugee populations. Ann Trop Med Parasitol. 1997 Sep;91(6):591-602. doi:10.1080/00034989760680

125. Hassan K, Sullivan KM, Yip R, Woodruff BA. Factors associated with anemia in refugee children. J Nutr. 1997 Nov;127(11):2194-8. doi:10.1093/jn/127.11.2194. PMID:9349847

126. Omar MS. A survey of bancroftian filariasis among South-East Asian expatriate workers in Saudi Arabia. Trop Med Int Health. 1996 Apr;1(2):155-60. doi:10.1111/j.1365-3156.1996.tbooo21.x

127. Nimri LF, Hijazi S. Rotavirus-associated diarrhoea in children in a refugee camp in Jordan. J Diarrhoeal Dis Res. 1996 Mar;14(1):14. PMID:8708326

128. Shidrawi RG, Skidmore SJ, Coleman JC, Dayton R, Murray-Lyon IM. Hepatitis E--an important cause of imported non-A, non-B hepatitis among migrant workers in Qatar. J Med Virol. 1994 Aug;43(4):412-4. doi:10.1002/jmv.1890430416

129. Miller LC, Timouri M, Wijnker J, Schaller JG. Afghan refugee children and mothers. Arch Pediatr Adolesc Med. 1994 Jul;148(7):704-8. doi:10.1001/archpedi.1994.02170070042007

130. Yip R, Sharp TW. Acute malnutrition and high childhood mortality related to diarrhea. Lessons from the 1991 Kurdish refugee crisis. JAMA. 1993 Aug 4;270(5):587-90

131. Marnell F, Guillet A, Holland C. A survey of the intestinal helminths of refugees in Juba, Sudan. Ann Trop Med Parasitol. 1992 Aug;86(4):387-93. doi:10.1080/00034983.1992.11812682

132. Kronfol NM, Sibai AM, Rafeh N. The impact of civil disturbances on the migration of physicians: the case of Lebanon. Med Care. 1992 Mar;30(3):208-15. doi:10.1097/00005650-199203000-00003

133. Lienhardt C, Ghebray R, Candolfi E, Kien T, Hedlin G. Malaria in refugee camps in eastern Sudan: a sero-epidemiological approach. Ann Trop Med Parasitol. 1990 Jun;84(3):215-22. doi:10.1080/00034983.1990.11812460

134. Spinaci S, De Virgilio G, Bugiani M, Linari D, Bertolaso G, Elo O. Tuberculin survey among Afghan refugee children. Tuberculosis control programme among Afghan refugees in North West Frontier Province (NWFP) Pakistan. Tubercle. 1989 Jun;70(2):8392. doi:10.1016/0041-3879(89)90032-9

135. Godfrey N, Kalache A. Health needs of older adults displaced to Sudan by war and famine: questioning current targeting practices in health relief. Soc Sci Med. 1989;28(7):707-13. doi:10.1016/0277-9536(89)90218-9.

136. Downing R. A tale of two clinics--primary health care in refugee settings: lessons from Sudan and Somalia. Soc Sci Med. 1989;28(10):1053-8. doi:10.1016/0277-9536(89)90387-0

137. Suleman M. Malaria in Afghan refugees in Pakistan. Trans R Soc Trop Med Hyg. 1988;82(1):44-7. doi:10.1016/00359203(88)90257-X

138. Halbert RJ, Simon RR, Hood H. Providing health care in war-torn rural Afghanistan. Lancet. 1988 May 28;1(8596):1214-5. doi:10.1016/s0140-6736(88)92022-3

139. Kronfol NM, Rafeh N. The impact of civil disturbances on the migration of physicians: the case of Lebanon. Health Matrix. 1987 Spring;5(1):29-35. PMID:10282256

140. Lenehan GP. Profiles in courage: humanitarian medical aid to victims and refugees of the Soviet-Afghan war. J Emerg Nurs. 1986 Sep-Oct;12(5):23A-31A. PMID:3534406 
141. Anderson JD, Bentley CC. Role of community health workers in trachoma control. Case study from a Somali refugee camp. Trop Doct. 1986 Apr;16(2):66-9. doi:10.1177/004947558601600209

142. Shears P. Tuberculosis control in Somali refugee camps. Tubercle. 1984 Jun;65(2):111-6. doi:10.1016/0041-3879(84)90062-X

143. Bella H, de C Marshall TF, Omer AH, Vaughan JP. Migrant workers and schistosomiasis in the Gezira, Sudan. Trans R Soc Trop Med Hyg. 1980;74(1):36-9. doi:10.1016/0035-9203(80)90008-5

144. Nadim A, Amini H, Malek-Afzali H. Blood pressure and rural--urban migration in Iran. Int J Epidemiol. 1978 Jun;7(2):131-8. doi:10.1093/ije/7.2.131

145. Ronaghy HA, Zeighami B, Agah T, Rouhani R, Zimmer SP. Migration of Iranian nurses to the U.S.: a study of one school of nursing in Iran. Int Nurs Rev. 1975 May-Jun;22(3):87-8. PMID:1040626

146. Krause S, Williams H, Onyango MA, Sami S, Doedens W, Giga N, et al. Reproductive health services for Syrian refugees in Zaatri Camp and Irbid City, Hashemite Kingdom of Jordan: an evaluation of the Minimum Initial Services Package. Confl Health. 2015 Feb 2;9(Suppl. 1):S4. doi:10.1186/1752-1505-9-S1-S4

147. Al-Rousan T, Schwabkey Z, Jirmanus L, Nelson BD. Health needs and priorities of Syrian refugees in camps and urban settings in Jordan: perspectives of refugees and health care providers. East Mediterr Health J. 2018 Jun 10;24(3):243-253. doi:10.26719/2018.24.3.243

148. Abbasi-Kangevari M, Amin K, Kolahi AA. Antenatal care utilisation among Syrian refugees in Tehran: a respondent driven sampling method. Women Birth. 2020 Mar;33(2):e117-e121. doi:10.1016/j.wombi.2019.02.001

149. Abdo N, Abu Naqera K, Batieha A, Abu Zayed I. Catastrophic health expenditure among ex-Gazan families in Jerash camp, Jordan. Public Health. 2020 Sep;186:101-106. doi:10.1016/j.puhe.2020.07.014

150. Afifi TD, Afifi WA, Acevedo Callejas M, Shahnazi A, White A, Nimah N. The functionality of communal coping in chronic uncertainty environments: the context of Palestinian refugees in Lebanon. Health Commun. 2019 Nov;34(13):15851596. doi:10.1080/10410236.2018.1514682

151. Akhtar A, Giardinelli L, Bawaneh A, Awwad M, Naser H, Whitney C, et al. Group problem management plus (gPM+) in the treatment of common mental disorders in Syrian refugees in a Jordanian camp: study protocol for a randomized controlled trial. BMC Public Health. 2020 Mar 26;20(1):390. doi:10.1186/s12889-020-08463-5

152. Al Abri S, Kowada A, Yaqoubi F, Al Khalili S, Ndunda N, Petersen E. Cost-effectiveness of IGRA/QFT-Plus for TB screening of migrants in Oman. Int J Infect Dis. 2020 Mar;92S:S72-S77. doi:10.1016/j.ijid.2020.03.010

153. Al Qadire M, Aljezawi M, Al-Shdayfat N. Cancer awareness and barriers to seeking medical help among Syrian refugees in Jordan: a baseline study. J Cancer Educ. 2019 Feb;34(1):19-25. doi:10.1007/s13187-017-1260-1

154. Alahmad B, Kurdi H, Colonna K, Gasana J, Agnew J, Fox MA. COVID-19 stressors on migrant workers in Kuwait: cumulative risk considerations. BMJ Glob Health. 2020 Jul;5(7):e002995. doi:10.1136/bmjgh-2020-002995

155. Alghadir AH, Zafar H, Iqbal ZA. Experiences of overseas trained physical therapists working in Saudi Arabia: an observational study. Int J Environ Res Public Health. 2020 May 13;17(10):3406. doi:10.3390/ijerph17103406

156. Al-Smadi AM, Tawalbeh LI, Gammoh OS, Ashour A, Tayfur M, Attarian H. The prevalence and the predictors of insomnia among refugees. J Health Psychol. 2019 Jul;24(8):1125-1133. doi:10.1177/1359105316687631

157. Azizi N, Delgoshaei B, Aryankhesal A. Lived experience of Afghan refugees in Iran concerning primary health care delivery. Disaster Med Public Health Prep. 2019 Dec;13(5-6):868-873. doi:10.1017/dmp.2018.169

158. Balahbib A, Amarir F, Bouhout S, Adlaoui EB, Rhajaoui M, Sadak A. Retrospective study on imported schistosomiasis in Morocco between 2005 and 2017. Trop Doct. 2020 Oct;50(4):317-321. doi:10.1177/0049475520928195

159. Bani Hani A, Abu Abeeleh M, Al Smady M, Shaban M, Al Kharabsheh M, Al-Tamimi Z, et al. Heart disease in adult Syrian refugees: experience at Jordan University Hospital. Ann Glob Health. 2019 Mar 14;85(1):36. doi:10.5334/aogh.2474

160. Boughattas S, Behnke JM, Al-Sadeq D, Ismail A, Abu-Madi M. Cryptosporidium spp., prevalence, molecular characterisation and socio-demographic risk factors among immigrants in Qatar. PLoS Negl Trop Dis. 2019 Oct 29;13(10):e0o07750. doi:10.1371/journal. pntd.0007750

161. Dhaini SR, Dumit N, Honein-Abouhaidar G, Al Zaru IM, Gharaibeh M, Reynolds NR, et al. Perspectives of registered nurses on refugee healthcare in Lebanon and Jordan (PROfILE): a multi-site cross-sectional study protocol. J Adv Nurs. 2020 Jan;76(1):328336. doi:10.1111/jan.14217

162. Dumit NY, Honein-AbouHaidar G. The impact of the Syrian refugee crisis on nurses and the healthcare system in Lebanon: a qualitative exploratory study. J Nurs Scholarsh. 2019 May;51(3):289-298. doi:10.1111/jnu.12479

163. El Hechi MW, Khalifeh JM, Ramly EP, Elahad JA, Bonde A, Velmahos GC, et al. Refugee access to surgical care in Lebanon: a post hoc analysis of the SCAR Study. J Surg Res. 2019 Aug;240:175-181. doi:10.1016/j.jss.2019.03.007

164. El-Khatib Z, El-Halabi S, Abu Khdeir M, Khader YS. Children Immunization App (CImA), low-cost digital solution for supporting syrian refugees in Zaatari Camp in Jordan - general description. Stud Health Technol Inform. 2020 Jun 23;271:117-120. doi:10.3233/SHTI200086

165. Firdous SN, Zulfiqar Hyder Naqvi SM, Akhter M. Factors affecting migration abroad of dental practitioners from Karachi: a cross-sectional survey. J Pak Med Assoc. 2019 Oct;69(10):1531-1538. PMID:31622311 
166. Hamoudi R, Saheb Sharif-Askari N, Saheb Sharif-Askari F, Abusnana S, Aljaibeji H, Taneera J, et al. Prediabetes and diabetes prevalence and risk factors comparison between ethnic groups in the United Arab Emirates. Sci Rep. 2019 Nov 25;9(1):17437. doi:10.1038/s41598-019-53505-7

167. Hassanpour G, Mohebali M, Mirhendi H, Zeraati H, Raeisi A, Keshavarz H. Asymptomatic malaria infections among immigrants in malaria-elimination programmed areas of south eastern Iran may threaten malaria eradication. Travel Med Infect Dis. 2019 Sep-Oct;31:101426. doi:10.1016/j.tmaid.2019.05.012. Epub 2019 May 18. PMID:31112764

168. Ibrahim H, Al Sharif FZ, Satish KP, Hassen L, Nair SC. Should I stay or should I go now? The impact of "pull" factors on physician decisions to remain in a destination country. Int J Health Plann Manage. 2019 Oct;34(4):e1909-e1920. doi:10.1002/hpm

169. Jamal Z, Alameddine M, Diaconu K, Lough G, Witter S, Ager A, Fouad FM. Health system resilience in the face of crisis: analysing the challenges, strategies and capacities for UNRWA in Syria. Health Policy Plan. 2020 Feb 1;35(1):26-35. doi:10.1093/heapol/ czz129

170. Kaafarani HMA, Khalifeh JM, Ramly EP, Simon D, Safa R, Khalil L, et al. A nationwide, systematic, and comprehensive assessment of surgical capacity in Lebanon: results of the Surgical Capacity in Areas With Refugees (SCAR) Study. Ann Surg. 2019 Jun;269(6):1206-1214. doi:10.1097/SLA.0000000000002687

171. Kanani K, Amr ZS, Shadfan B, Khorma R, Rø G, Abid M, Gabrielli AF, Haskew J. Cutaneous leishmaniasis among Syrian refugees in Jordan. Acta Trop. 2019 Jun;194:169-171. doi:10.1016/j.actatropica.2019.04.005

172. Khachfe HH, Zayyoun FJ, Sharif-Askari E, Ramadan W, Hallal N, Khachfe HM. Effect of leishmaniasis on the performance of elementary school students: a case study among Syrian refugees in some Bekaa (Lebanon) area schools. J Epidemiol Glob Health. 2019 Dec;9(4):266-273. doi:10.2991/jegh.k.190915.001

173. Khaled SM, Gray R. Depression in migrant workers and nationals of Qatar: an exploratory cross-cultural study. Int J Soc Psychiatry. 2019 Aug;65(5):354-367. doi:10.1177/0020764019850589

174. Kmeid M, Azouri H, Aaraj R, Bechara E, Antonios D. Vaccine coverage for Lebanese citizens and Syrian refugees in Lebanon. Int Health. 2019 Nov 13;11(6):568-579. doi:10.1093/inthealth/ihzo23

175. Mansour Z, Hamadeh R, Rady A, Danovaro-Holliday MC, Fahmy K, Said R, Brandt L, Warrak R, Ammar W. Vaccination coverage in Lebanon following the Syrian crisis: results from the district-based immunization coverage evaluation survey 2016. BMC Public Health. 2019 Jan 14;19(1):58. doi:10.1186/s12889-019-6418-9

176. Noaman BR, Khalid RF, Fattah LD. Maternal dental health knowledge and its relation to the dental caries experience of their children in Mamyzawa camp of refugees in Erbil, Iraq. Acta Med Acad. 2019 Dec;48(3):294-302. doi:10.5644/ama2006-124.270

177. Noubani A, Diaconu K, Ghandour L, El Koussa M, Loffreda G, Saleh S. A community-based system dynamics approach for understanding factors affecting mental health and health seeking behaviors in Beirut and Beqaa regions of Lebanon. Global Health. 2020 Mar 30;16(1):28. doi:10.1186/s12992-020-00556-5

178. Oladeji O, Campbell P, Jaiswal C, Chamla D, Oladeji B, Ajumara CO, et al. Integrating immunisation services into nutrition sites to improve immunisation status of internally displaced persons' children living in Bentiu protection of civilian site, South Sudan. Pan Afr Med J. 2019 Jan 16;32:28. doi:10.11604/pamj.2019.32.28.15464

179. Pierce H. Reproductive health care utilization among refugees in Jordan: Provisional support and domestic violence. Womens Health (Lond). 2019 Jan-Dec;15:1745506519861224. doi:10.1177/1745506519861224

180. Rajati F, Hamzeh B, Pasdar Y, Safari R, Moradinazar M, Shakiba E, et al. Prevalence, awareness, treatment, and control of hypertension and their determinants: Results from the first cohort of non-communicable diseases in a Kurdish settlement. Sci Rep. 2019 Aug 27;9(1):12409. doi:10.1038/s41598-019-48232-y

181. Richa S, Herdane M, Dwaf A, Bou Khalil R, Haddad F, El Khoury R, et al. Trauma exposure and PTSD prevalence among Yazidi, Christian and Muslim asylum seekers and refugees displaced to Iraqi Kurdistan. PLoS One. 2020 Jun 24;15(6):e0233681. doi:10.1371/journal.pone.0233681

182. Saikal SL, Ge L, Mir A, Pace J, Abdulla H, Leong KF, et al. Skin disease profile of Syrian refugees in Jordan: a field-mission assessment. J Eur Acad Dermatol Venereol. 2020 Feb;34(2):419-425. doi:10.1111/jdv.15909

183. Salim NA, ElSa'aideh BB, Maayta WA, Hassona YM. Dental services provided to Syrian refugee children in Jordan: a retrospective study. Spec Care Dentist. 2020 May;40(3):260-266. doi:10.1111/scd.12460

184. Sanders AM, Abdalla Z, Elshafie BE, Nute AW, Long EF, Aziz N, et al. Prevalence of trachoma within refugee camps serving South Sudanese refugees in White Nile State, Sudan: Results from population-based surveys. PLoS Negl Trop Dis. 2019 Jun 13;13(6):e0007491. doi:10.1371/journal.pntd.0007491

185. Spiegel PB, Cheaib JG, Aziz SA, Abrahim O, Woodman M, Khalifa A, et al. Cancer in Syrian refugees in Jordan and Lebanon between 2015 and 2017. Lancet Oncol. 2020 May;21(5):e280-e291. doi:10.1016/S1470-2045(20)30160-1

186. Stevenson K, Alameddine R, Rukbi G, Chahrouri M, Usta J, Saab B, et al. High rates of maternal depression amongst Syrian refugees in Lebanon - a pilot study. Sci Rep. 2019 Aug 14;9(1):11849. doi:10.1038/s41598-019-48247-5

187. Strømme EM, Haj-Younes J, Hasha W, Fadnes LT, Kumar B, Igland J, et al. Health status and use of medication and their association with migration related exposures among Syrian refugees in Lebanon and Norway: a cross-sectional study. BMC Public Health. 2020 Mar 17;20(1):341. doi:10.1186/s12889-020-8376-7

188. Tittle V, Bennett DL, Hajat S, Shishtawi A, Zeidan W, Abuzabaida F, et al. Antenatal care among Palestine refugees in Jordan: factors associated with UNRWA attendance. East Mediterr Health J. 2019 Mar 19;25(2):98-103. doi:10.26719/emhj.18.017 
189. Zaghloul MS, Saquib J, AlMazrou A, Saquib N. Mental health status of expatriate nurses in northcentral Saudi Arabia. J Immigr Minor Health. 2019 Dec;21(6):1233-1240. doi:10.1007/s10903-018-00853-7

190. Zoghi S, Emami M, Shahriarirad S, Vahedi R, Cheraghi MR, Zamiri B, et al. Human fascioliasis in nomads: a population-based serosurvey in southwest Iran. Infez Med. 2019 Mar 1;27(1):68-72. PMID:30882381

191. Alameddine M, Fouad FM, Diaconu K, Jamal Z, Lough G, Witter S, et al. Resilience capacities of health systems: accommodating the needs of Palestinian refugees from Syria. Soc Sci Med. 2019 Jan;220:22-30. doi:10.1016/j.socscimed.2018.10.018

192. Marzouk M, Kelley M, Fadhil I, Slama S, Longuere KS, Ariana P, Carson G, Marsh V. "If I have a cancer, it is not my fault I am a refugee": a qualitative study with expert stakeholders on cancer care management for Syrian refugees in Jordan. PLoS One. 2019 Sep 27;14(9):e0222496. doi:10.1371/journal.pone.0222496

193. Monitoring the building blocks of health systems: a handbook of indicators and their measurement strategies. Geneva: World Health Organization; 2010.

194. Akik C, Ghattas H, Mesmar S, Rabkin M, El-Sadr WM, Fouad FM. Host country responses to non-communicable diseases amongst Syrian refugees: a review. Confl Health. 2019 Mar 22;13:8. doi:10.1186/s13031-019-0192-2

195. Talhouk R, Balaam M, Toombs AL, Garbett A, Akik C, Ghattas H, et al. Involving Syrian refugees in design research: lessons learnt from the field. In: Proceedings of the 2019 on Designing Interactive Systems Conference. 2019:1583-94. https://doi. org/10.1145/3322276.3322335

196. Lyles E, Hanquart B, Chlela L, Woodman M, LHAS Study Team, Fouad FM, et al. Health service access and utilization among Syrian refugees and affected host communities in Lebanon. J Refugee Stud. 2018;31(1):104-30. https://doi.org/10.1093/jrs/fexo14

197. Legido-Quigley H, Pocock N, Tan ST, Pajin L, Suphanchaimat R, Wickramage K, McKee M, Pottie K. Healthcare is not universal if undocumented migrants are excluded. BMJ. 2019 Sep 16;366:1416o. doi:10.1136/bmj.14160

198. How Syria's displaced doctors became Turkey's new workforce. London: apolitical; 2019 (https://apolitical.co/en/solution_article/ syria-displaced-doctors-turkey-workforce, accessed 24 Sepember 2021).

199. Kayali N. Syrian refugees navigate Turkey's shifting health care terrain. Middle East Research and Information Project. 2020;297.

200. Public health round-up. Bull World Health Organ. 2015;93(12):820-1.

201. Arziman I. Field organization and disaster medical assistance teams. Turk J Emerg Med. 2016 Mar 9;15(Suppl 1):11-9. doi:10.5505/1304.7361.2015.79923 